\title{
DEMOKRASI DI NEGARA HUKUM YANG BERETIKA/BERMORAL
}

\section{Desem Soinbala}

\author{
Nim;2121B1001 \\ desemsoinbala21@gmail.com \\ IIK STRADA INDONESIA
}

\begin{abstract}
Democracy is good, especially which existed in law-based (rechtsstaat) countries and not power-based (machtsstaat) countries. Democracy in law-based country should match the ethic principles and morality so it could run in the right track. Government is based on constitutional system (foundation system) not based on absolutism (unlimited power). Article is about the ongoing implementation of democracy in Indonesia; which should suit the democracy values, such as ending argument in peaceful and democratic way, ensuring the peaceful changing in community and holding regular leader's changing.
\end{abstract}

\section{ABSTRAK}

Demokrasi memang baik adanya, terutama demokrasi yang dilaksanakan di negara yang berdasarkan atas hukum (rechtsstaat) bukan berdasarkan kekuasaan belaka (machtsstaat). Demokrasi di negara hukum juga haruslah sesuai dengan prinsip-prinsip etika dan juga moralitas sehingga selalu berjalan pada rel yang benar. Pemerintahan pun berdasarkan atas sistim konstitusi (hukum dasar) tidak berdasar absolutisme (kekuasaan tak terbatas). Artikel ini membahas tentang pelaksanaan demokrasi di Indonesia yang sedang berjalan sekarang ini; yang seharusnya sesuai dengan nilai-nilai demokrasi, seperti: menyelesaikan 
perselisihan dengan damai dan secara melembaga, menjamin terselenggaranya perubahan secara damai dalam suatu masyarakat yang sedang berubah dan menyelenggarakan pergantian pimpinan secara teratur. 


\section{PENDAHULUAN}

Ada bermacam-macam istilah untuk demokrasi, antara lain: demokrasi konstitusionil, demokrasi parlementer, demokrasi terpimpin, demokrasi Pancasila, demokrasi rakyat, demokrasi Soviet, demokrasi nasional dan lain-lain.Istilah demokrasi berasal dari kata Yunani, demos berarti rakyat, kratos atau kratein berarti kekuasaan atau berkuasa. Istilah demokrasi berarti 'rakyat yang berkuasa' atau 'government or rule by the people'. Dari begitu banyak aliran demokrasi ada dua aliran yang paling penting yaitu: demokrasi konstitusionil dan demokrasi yang mendasarkan dirinya atas komunisme. Kedua kelompok aliran demokrasi ini awalnya berasal dari Eropa, namun sesudah Perang Dunia II didukung oleh negara-negara Asia contoh: India, Pakistan, Filipina dan Indonesia, yang mencitacitakan demokrasi konstitusionil. Selain itu, ada negara-negara di Asia yang mendasarkan diri atas azas komunisme yaitu: RRC, Korea Utara dan lain-lain.

\section{PEMBAHASAN}

\section{Demokrasi di Indonesia}

Demokrasi yang dianut di Indonesia yaitu demokrasi yang berdasarkan Pancasila.Beberapa nilai pokok dari demokrasi konstitusionil cukup jelas tersirat di dalam Undang-Undang Dasar 1945, yang menyebut secara eksplisit dua prinsip yang menjiwai naskah Undang-Undang Dasar 1945 dan dicantumkan dalam Penjelasan mengenai Sistem Pemerintahan Negara yaitu: (1) Indonesia adalah negara yang berdasarkan atas hukum (rechtsstaat). Negara Indonesia berdasarkan atas hukum (rechtsstaat), tidak berdasarkan kekuasaan belaka (machtsstaat); (2) sistim konstitusionil, yaitu pemerintahan berdasarkan atas sistim konstitusi (hukum dasar), tidak bersifat absolutisme (kekuasaan yang tidak terbatas). Berdasarkan dua istilah rechtsstaat dan sistim konstitusi, jelaslah bahwa demokrasi yang menjadi dasar dari Undang-Undang Dasar 1945, ialah demokrasi konstitusionil. Corak khas dari demokrasi Indonesia yaitu: kerakyatan yang dipimpin oleh hikmah kebijaksanaan dalam permusyawaratan/ perwakilan, dimuat dalam Pembukaan Undang-Undang Dasar 
Ciri khas dari demokrasi konstitusionil adalah gagasan bahwa Pemerintahan yang demokratis adalah pemerintah yang terbatas kekuasaannya dan tidak dibenarkan bertindak sewenang-wenang terhadap warga negaranya.Pembatasanpembatasan atas kekuasaan Pemerintah tercantum dalam konstitusi; karena itu sering disebut pemerintah berdasar konstitusi (constitutional government).Jadi, constitutional government sama dengan limited government atau restrained government. Lord Acton, seorang ahli sejarah Inggris, merumuskan gagasan, kekuasaan pemerintah perlu dibatasi. Pemerintahan selalu diselenggarakan oleh manusia, dan pada manusia itu tanpa kecuali melekat banyak kelemahan. Dalilnya yang terkenal adalah power tends to corrupt, but absolute power corrupts absolutely; yang berarti manusia yang mempunyai kekuasaan cenderung untuk menyalahgunakan kekuasaan itu, tetapi manusia yang mempunyai kekuasaan tak terbatas pasti akan menyalahgunakannya. Pembatasan atas kekuasaan negara sebaiknya diselenggarakan dengan suatu konstitusi tertulis, yang dengan tegas menjamin hak-hak azasi dari warga negara.. Kekuasaan perlu dibagi sehingga kesempatan penyalahgunaan diperkecil, dengan cara menyerahkannya kepada beberapa orang atau badan dan tidak memusatkan kekuasaan pemerintahan dalam tangan satu orang atau satu badan. Perumusan yuridis dari prinsip-prinsip ini terkenal dengan istilah rechtsstaat (negara hukum) dan rule of law.

Demokrasi tidak merupakan suatu yang statis. Sesudah Perang Dunia II, negara demokratis telah melepaskan pandangan bahwa peranan negara hanya terbatas pada mengurus kepentingan bersama. Sekarang negara turut bertanggungjawab atas kesejahteraan rakyat, karena itu negara aktif untuk menaikkan taraf kehidupan warga negaranya. Gagasan ini ada pada konsep welfare state (negara kesejahteraan) atau social service state. Di abad ke-20, demokrasi tidak lagi membatasi diri pada aspek politik saja tetapi meluas mencakup segi-segi ekonomi sehingga demokrasi menjadi demokrasi ekonomi.

Menurut Friedrich (1963), konstitusionalisme adalah pemerintah merupakan suatu kumpulan aktivitas yang diselenggarakan atas nama rakyat, tetapi tunduk kepada beberapa pembatasan yang dimaksud untuk memberi jaminan bahwa 
kekuasaan yang diperlukan pemerintahan itu tidak disalahgunakan oleh mereka yang mendapat tugas untuk memerintah. Dalam gagasan konstitusionalisme, undang-undang dasar dipandang sebagai suatu lembaga yang mempunyai fungsi khusus, yaitu menentukan dan membatasi kekuasaan pemerintah di satu pihak, dan di pihak lain menjamin hak-hak azasi dari warga negaranya.Undang-undang dasar dianggap sebagai perwujudan dari hukum tertinggi yang harus dipatuhi oleh negara dan pejabat-pejabat pemerintah: pemerintahan berdasar hukum, bukan oleh manusia.

Pada permulaan abad ke-20, gagasan mengenai perlunya pembatasan perlu dirumuskan secara yuridis. Ahli hukum Eropa Barat Kontinental seperti: Immanuel Kant dan Friedrich Julius Stahl memakai istilah rechtsstaat, sedangkan ahli Anglo Saxon seperti A.V. Dicey memakai istilah rule of law. Stahl menyebut empat unsur-unsur rechtsstaat dalam arti klasik, yaitu: (1) hak-hak manusia; (2) pemisahan atau pembagian kekuasaan untuk menjamin hak-hak itu (di negaranegara eropa kontinental biasanya disebut trias politica); (3) pemerintah berdasarkan peraturan-peraturan (wetmatigheid van bestuur); (4) peradilan administrasi dalam perselisihan.

Unsur-unsur rule of law dalam arti yang klasik, seperti yang dikemukakan oleh A.V. Dicey dalam Introduction to the Law of the Constitution mencakup: (1) supremasi aturan-aturan hukum (supremacy of the law), tidak adanya kekuasaan sewenang-wenang (absence of arbitrary power), dalam arti bahwa seseorang hanya boleh dihukum karena melanggar hukum; (2) kedudukan yang sama dalam menghadapi hukum (equality before the law); (3) terjaminnya hak-hak manusia oleh undang-undang (di negara lain oleh undang-undang dasar) serta keputusankeputusan pengadilan. 
Syarat-syarat dasar untuk terselenggaranya pemerintah yang demokratis di bawah Rule of Law adalah: (1) perlindungan konstitusionil (konstitusi selain menjamin hak-hak individu juga menentukan cara prosedur memperoleh perlindungan atas hak-hak yang dijamin); (2) badan kehakiman yang bebas dan tidak memihak (independent and impartial tribunals); (3) pemilihan umum yang bebas; (4) kebebasan untuk menyatakan pendapat; (5) kebebasan untuk berserikat/berorganisasi dan beroposisi; (6) pendidikan kewarganegaraan (civic education)

\section{Nilai-Nilai Demokrasi}

Mayo (1960) memberi definisi bahwa sistem politik yang demokratis ialah di mana kebijaksanaan umum ditentukan atas dasar mayoritas oleh wakil-wakil yang diawasi secara efektif oleh rakyat dalam pemilihan-pemilihan berkala yang didasarkan atas prinsip kesamaan politik dan diselenggarakan dalam suasana terjaminnya kebebasan politik. Beberapa nilai (values) demokrasi yang dirumuskan oleh Mayo antara lain: (1) menyelesaikan perselisihan dengan damai dan secara melembaga; (2) menjamin terselenggaranya perubahan secara damai dalam suatu masyarakat yang sedang berubah; (3) menyelenggarakan pergantian pimpinan secara teratur; (4) membatasi pemakian kekerasan sampai minimum; (5) mengakui serta menganggap wajar adanya keanekaragaman dalam masyarakat yang tercermin dalam keanekaragaman pendapat, kepentingan serta tingkah laku; (6) menjamin tegaknya keadilan..

Untuk melaksanakan nilai-nilai demokrasi dapat terselenggara dengan baik, maka diperlukan beberapa lembaga antara lain: (1) pemerintahan yang bertanggung-jawab; (2) dewan perwakilan rakyat yang mewakili golongangolongan dan kepentingan-kepentingan dalam masyarakat dan yang dipilih dengan pemilihan umum yang bebas dan rahasia dan atas dasar sekurangkurangnya dua calon untuk setiap kursi; (3) suatu organisasi politik yang mencakup satua atau lebih partai politik (sistim dwipartai, multi-partai); (4) pers dan media massa yang bebas untuk menyatakan pendapat; (5) sistim peradilan yang bebas untuk menjamin hak-hak azasi dan mempertahankan keadilan. 


\section{Negara Hukum}

Di negara hukum, kekuasaan negara haruslah dijalankan atas dasar hukum yang adil dan baik. Unsur-unsur di dalam negara hukum yaitu: hubungan antara yang memerintah dan yang diperintah tidak berdasarkan kekuasaan melainkan berdasarkan suatu norma objektif, yang juga mengikat pihak yang memerintah; serta norma objektif itu harus memenuhi syarat bahwa tidak hanya secara formal, melainkan dapat dipertahankan berhadapan dengan idea hukum. Hukum menjadi landasan setiap tindakan negara. Negara menyelenggarakan dan menjalankan tugasnya berdasarkan hukum dengan alas an, seperti demi kepastian hukum, tuntutan perlakuan yang sama, legitimasi demokrasi, dan tuntutan akal budi.

Hal-hal mendasar sebagai unsur-unsur dari suatu negara hukum yaitu: hak azasi manusia dihargai sesuai dengan harkat dan martabat manusia; adanya pemisahan atau pembagian kekuasaan untuk menjamin hak-hak itu; pemerintahan dijalankan berdasarkan peraturan perundang-undangan; adanya peradilan administrasi dalam perselisihan antara rakyat dan pemerintah. Ciri-ciri dominan dari sebuah negara hukum adalah: (1) kekuasaan dijalankan sesuai dengan hukum positif yang berlaku; (2) kegiatan negara di bawah kontrol kekuasaan kehakiman yang efektif; (3) berdasarkan sebuah undangundang yang menjamin Hak Azasi Manusia; (4) menuntut pembagian kekuasaan.

Negara hukum berarti alat-alat negara mempergunakan kekuasaannya berdasarkan hukum yang berlaku, dan dengan cara yang ditentukan oleh hukum itu. Tujuan dari suatu perkara adalah agar dijatuhi suatu putusan sesuai dengan kebenaran. Karena itu semua pihak berhak atas pembelaan atau bantuan hukum.

\section{Demokrasi di Negara Hukum yang Beretika dan bermoral}

\section{Pengertian Etika dan Moralitas}

Pengertian etika perlu kita bedakan dengan moralitas. Moralitas adalah sistem nilai tentang bagaimana kita harus hidup secara baik sebagai manusia. Sistem nilai ini terkandung dalam ajaran berbentuk petuah-petuah, nasihat, wejangan, peraturan, perintah dan semacamnya yang diwariskan secara turun- 
temurun melalui agama atau kebudayaan tertentu tentang bagaimana manusia harus hidup secara baik agar ia benar-benar menjadi manusia yang baik. Moralitas adalah tradisi kepercayaan, dalam agama atau kebudayaan tentang perilaku yang baik dan buruk

Sedangkan etika perlu dipahami sebagai sebuah cabang filsafat yang berbicara mengenai nilai dan norma moral yang menentukan perilaku manusia dalam hidupnya. Etika sangat menekankan pendekatan yang kritis dalam melihat dan menggumuli nilai dan norma moral tersebut serta permasalahanpermasalahan yang timbul dalam kaitan dengan nilai dan norma moral itu. Etika adalah sebuah refleksi kritis dan rasional mengenai nilai dan norma moral yang menentukan dan terwujud dalam sikap dan pola perilaku manusia, baik secara pribadi maupun sebagai kelompok.

Menurut Suseno (1987), etika adalah sebuah ilmu dan bukan sebuah ajaran. Yang memberi kita norma tentang bagaimana kita harus hidup adalah moralitas. Etika justru hanya melakukan

refleksi kritis atas norma atau ajaran moral tersebut. Moralitas adalah petunjuk konkret yang siap pakai tentang bagaimana kita harus hidup. Sedangkan etika adalah perwujudan dan pengejawantahan secara kritis dan rasional ajaran moral yang siap pakai itu. Keduanya mempunyai fungsi yang sama, yaitu memberi kita orientasi bagaimana dan ke mana kita melangkah dalam hidup ini. Bedanya, moralitas langsung mengatakan kepada kita: inilah caranya Anda harus melangkah. Sedangkan etika justru mempersoalkan: apakah saya harus melangkah dengan cara itu dan mengapa harus dengan cara itu.

Jadi moralitas adalah sebuah pranata seperti halnya agama, politik, bahasa dan sebagainya yang sudah ada sejak dahulu kala dan diwariskan secara turuntemurun. Sebaliknya, etika adalah sikap kritis setiap pribadi dan kelompok 
masyarakat dalam merealisasikan moralitas itu. Tidaklah mengherankan bila moralitas bisa saja sama, tetapi sikap etis bisa saja berbeda antara satu orang dengan orang lainnya dalam masyarakat yang sama, atau antara masyarakat yang satu dengan masyarakat yang lainnya.

Etika adalah refleksi kritis terhadap moralitas, karena itu etika tidak bermaksud untuk orang bertindak sesuai dengan moralitas begitu saja. Etika, menghimbau orang untuk bertindak sesuai dengan moralitas, tetapi bukan karena tindakan itu diperintahkan oleh moralitas melainkan karena ia sendiri tahu bahwa hal itu memang baik baginya. la sendiri sadar secara kritis dan rasional bahwa ia memang sudah sepantasnya bertindak seperti itu. Atau, jika ia bertindak tidak sebagaimana yang diperintahkan oleh moralitas, orang itu bertindak tidak sesuai dengan moralitas bukan karena ikutikutan atau sekedar mau lain, melainkan karena ia punya alasan rasional untuk itu. la bertindak berdasarkan pertimbangan, walaupun itu bertentangan dengan moralitas, adalah baik baginya dan bagi masyarakat karena alasan-alasan yang rasional.

Etika berusaha menggugah kesadaran manusia untuk bertindak secara otonom dan bukan secara heteronom. Etika membantu manusia untuk bertindak secara bebas dan dapat dipertanggungjawabkan karena setiap tindakannnya selalu lahir dari keputusan pribadi yang bebas dengan selalu bersedia untuk mempertanggung-jawabkan tindakannya itu karena memang ada alasan-alasan dan pertimbangan-pertimbangan yang kuat mengapa ia bertindak begitu atau begini. Kebebasan dan tanggung-jawab adalah kondisi dasar bagi pengambilan keputusan dan tindakan yang etis, dengan suara hati melainkan peran yang sangat sentral. 
Dalam kaitan dengan nilai dan norma, kita menemukan ada dua etika yaitu etika deskriptif dan etika normatif. Etika deskriptif, yang berusaha meneropong secara kritis dan rasional sikap dan pola perilaku manusia dan apa yang dikejar oleh manusia dalam hidup ini sebagai sesuatu yang bernilai. Etika deskriptif berbicara mengenai fakta apa adanya, mengenai nilai dan pola perilaku manusia sebagai suatu fakta yang terkait dengan situasi dan realitas konkret yang membudaya. Sementara itu, etika normatif, yang berusaha menetapkan berbagai sikap dan pola perilaku ideal yang seharusnya dimiliki oleh manusia, atau apa yang seharusnya dijalankan oleh manusia, dan apa tindakan yang seharusnya diambil untuk mencapai apa yang bernilai dalam hidup ini. Etika normatif berbicara mengenai norma-norma yang menuntun tingkahlaku manusia, serta memberi penilaian dan himbauan kepada manusia untuk bertindak sebagaimana seharusnya berdasarkan norma-norma. la menghimbau manusia untuk bertindak yang baik dan menghindari yang jelek.

Secara umum kita dapat membedakan dua macam norma, yaitu norma khusus dan norma umum. Norma-norma khusus adalah aturan yang berlaku dalam bidang kegiatan atau kegiatan yang khusus, misalnya menyangkut aturan bermain dalam olah raga, aturan mengenai mengunjungi pasien di rumah sakit dan lain-lain. Sementara itu, norma umum mempunyai sifat keberlakuan yang lebih umum dan universal. Norma umum ada tiga macam, yaitu (1) norma sopan santun (etiket), menyangkut tata cara lahiriah dalam pergaulan sehari-hari yaitu: norma yang mengatur pola perilaku dan sikap lahiriah, misalnya: tata cara bertamu, duduk, makan, minum, dan sebagainya; (2) norma hukum, norma yang dituntut dengan tegas oleh masyarakat karena dianggap perlu demi keselamatan dan kesejahteraan masyarakat, keberlakuan norma hukum ini lebih tegas dan pasti, karena dijamin oleh hukuman terhadap para pelanggarnya; (3) norma moral, aturan mengenai sikap dan perilaku manusia sebagai manusia. Norma moral mengacu pada baik buruknya manusia sebagai manusia. Norma moral menjadi tolok ukur yang dipakai oleh masyarakat untuk menentukan baik 
buruknya manusia sebagai manusia, dan bukan kaitannya dengan tugas atau jabatan tertentu, bukan dalam kaitan dengan status sosial dan lain-lain.

Etika memberi manusia orientasi bagaimana ia menjalani hidupnya melalui rangkaian tindakan sehari-hari. Etika membantu manusia untuk mengambil sikap dan bertindak secara tepat dalam menjalani hidup ini. Etika membantu kita mengambil keputusan tentang tindakan apa yang mau kita lakukan dalam situasi tertentu dalam hidup kita sehari-hari. Etika membantu kita untuk membuat pilihan, pilihan nilai yang terjelma dalam sikap dan perilaku kita yang sangat mewarnai dan menentukan makna kehidupan kita.

Orientasi tindakan manusia selalu mengandaikan adanya sesuatu yang ingin dicapai sebagai tujuan akhir dari tindakan kita.Umumnya tujuan akhir dari seluruh tindakan yang kita ambil dan kita jalankan dalam kehidupan adalah kebahagiaan. Inilah nilai tertinggi yang selalu dikejar oleh setiap manusia di dalam hidupnya. Berhadapan dengan tujuan akhir inilah timbul persoalan, kita berhadapan dengan dua teori etika yang kita kenal sebagai etika deontologis dan etika teleologis. Tujuan atau akibat baik itu, baik untuk siapa? Untuk saya pribadi (juga para pengambil keputusan dan pelaksananya) atau baik untuk semua orang? Apakah tujuan itu baik hanya karena baik untuk 'saya' atau baik karena memang berguna bagi semua orang? Ini yang dinamakan egoisme dan etika utilitarianisma

\section{Etika Deontologi}

Deontologi berasal dari kata Yunani yang berarti kewajiban (duty). Etika deontologi menekankan kewajiban manusia untuk bertindak secara baik.Suatu tindakan itu baik bukan dinilai dan dibenarkan berdasarkan akibat atau tujuan baik dari tindakan itu, melainkan berdasarkan tindakan itu sendiri sebagai baik pada dirinya sendiri. Maka tindakan itu bernilai moral karena tindakan itu dilaksanakan berdasarkan kewajiban.

Etika deontologi sangat menekankan pentingnya motivasi, kemauan baik dan watak yang kuat dari para pelaku, terlepas dari akibat yang timbul dari perilaku para pelaku itu. Immanuel Kant (1734- 1804), kemauan baik harus dinilai baik 
pada dirinya sendiri terlepas dari apapun juga. Dalam menilai seluruh tindakan kita, kemauan baik harus selalu dinilai paling pertama dan menjadi kondisi dari segalanya. Dua hal pokok yang ditekankan oleh Kant adalah: (1) tidak ada hal di dunia ini yang bisa dianggap baik tanpa kualifikasi kecuali kemauan baik; (2) dengan menekankan kemauan baik, tindakan yang baik adalah tindakan yang tidak saja sesuai kewajiban melainkan tindakan yang dijalankan demi kewajiban.

Kant merumuskan pandangannya dalam tiga prinsip, yaitu (1) supaya suatu tindakan mempunyai nilai moral, tindakan itu harus dijalankan berdasarkan kewajiban; (2) nilai moral dari tindakan itu tidak tergantung pada tercapainya tujuan dari tindakan melainkan hanya tergantung pada kemauan baik yang mendorong seseorang untuk melakukan tindakan itu; (3) konsekwensi dari dua prinsip tersebut, kewajiban adalah hal yang niscaya dari tindakan yang dilaksanakan berdasarkan sikap hormat kepada hukum. Kant juga mengajukan dua perintah dalam etika yang sangat populer yaitu perintah bersyarat dan tidak bersyarat. Perintah bersyarat (imperatif hipotesis) adalah perintah yang dilaksanakan kalau orang menghendaki akibatnya, atau kalau akibat dari tindakan itu merupakan hal yang dikehendaki oleh orang tersebut. Perintah tak bersyarat (imperatif kategoris) adalah perintah yang dilaksanakan begitu saja tanpa mengharapkan akibatnya, atau tanpa mempedulikan apakah akibatnya tercapai dan berguna bagi orang tersebut atau tidak.

Kant juga menolak kalau orang melaksanakan perintah itu karena diperintahkan (heteronomi), melainkan menghendaki agar orang melaksanakan perintah itu karena memang ia sendiri mempunyai motivasi atau kemauan baik untuk melaksanakan perintah itu (otonomi). Pandangan Kant ini menimbulkan kesulitan pada teori deontologi yaitu apabila seseorang dihadapkan pada dua perintah atau kewajiban moral dalam suatu situasi yang sama, tetapi keduanya tidak bisa dilaksanakan sekaligus, bahkan keduanya saling meniadakan. W. D. Ross membantu memecahkan kesulitan ini dengan prisip prima faice.Dalam hidup kita menghadapi beberapa macam kewajiban moral. Kita dituntut untuk menemukan kewajiban terbesar untuk menemukan keseimbangan terbesar dari hal yang baik atas hal yang buruk dalam konteks khusus tertentu. Untuk menemukan keseimbangan perlu dibedakan antara kewajiban prima faice dan 
kewajiban aktual. Kewajiban prima faice adalah kewajiban yang selalu harus dilaksanakan kecuali dalam situasi khusus tertentu bertentangan dengan atau dikalahkan oleh suatu kewajiban yang sama atau yang lebih kuat. Perlu diingat dalam situasi semacam itu, setiap pribadi bebas menentukan sendiri apa yang harus diambil dengan didasarkan pada bisikan suara hatinya. John Stuart Mill, penganut deontology, dan juga Kant tidak bisa mengelakkan pentingnya akibat dari suatu tindakan untuk menentukan apakah tindakan itu baik atau buruk.Para penganut deontologi secara diam-diam menutup pentingnya akibat suatu tindakan, agar mampu memperlihatkan benarnya suatu tindakan berdasarkan nilai tindakan itu sendiri.

\section{Etika Teleologi}

Etika teleologi mengukur baik atau buruknya suatu tindakan berdasarkan tujuan yang mau dicapai dengan tindakan itu, atau berdasarkan akibat yang ditimbulkan oleh tindakan itu. Ada dua aliran etika teleologi yang berbeda yaitu egoism dan utilitarianisme. Egoisme adalah bahwa tindakan dari setiap orang pada dasarnya bertujuan untuk mengejar kepentingan pribadi dan memajukan dirinya sendiri. Satu-satunya tujuan dan juga kewajiban moral setiap pribadi adalah untuk mengejar kepentingannya dan memajukan diri sendiri. Ada dua macam egoisme utama yaitu: (1) egoisme etis adalah teori etika bahwa satusatunya tolok ukur mengenai baik buruknya suatu tindakan seseorang adalah kewajiban untuk mengusahakan kebahagiaan dan kepentingannya di atas kebahagiaan dan kepentingan orang lain; (2) egoisme psikologis adalah pandangan bahwa semua orang selalu dimotivasi oleh tindakan demi kepentingan dirinya belaka.Disebut egoisme psikologis karena terutama mau mengungkapkan bahwa motivasi itu satu-satunya dari manusia dalam melakukan tindakan apa saja adalah untuk mengejar kepentingannya sendiri. Utilitarianisme menilai baik buruknya suatu tindakan berdasarkan tujuan dan akibat dari tindakan itu bagi sebanyak mungkin orang.Disebut sebagai universalisme etis. Universalisme karena menekankan akibat baik yang berguna bagi sebanyak mungkin orang; etis karena menekankan akibat yang baik. 
Utilitarianisme karena menilai baik atau buruknya suatu tindakan berdasarkan kegunaan atau manfaat dari tindakan itu. Dua hal yang sangat positif dari etika utilitarianisme adalah: (1) rasionalitasnya, suatu tindakan dipilih, pada gilirannya dinilai baik, karena tindakan itu akan (atau telah) mendatangkan akibat baik yang lebih banyak daripada tindakan lainnya. Di sini ada sebuah neraca perhitungan; (2) universalitasnya, akibat atau nilai lebih yang hendak dicapai diukur berdasarkan banyaknya orang yang memperoleh manfaat dari nilai lebih itu. Etika utilitarianisme mengutamakan tindakan atau kebijaksanaan yang mengutamakan kepentingan banyak orang di atas kepentingan segelintir orang. Akibatnya etika utilitarianisme cenderung mengorbankan pihak-pihak yang kecil dan lemah yang seharusnya juga ikut menikmati manfaat itu. Itu berarti hak kelompok yang minoritas dan lemah terabaikan.

\section{Relativisme Etis}

Relativisme moral menunjukkan kenyataan bahwa norma-norma moral yang berlaku dalam pelbagai kebudayaan dan masyarakat tidak sama atau berbeda antara satu dengan yang lainnya. Dasar pemikirannya adalah nilai-nilai budaya (yang menjadi salah satu sumber, bahkan mungkin sumber utama norma-norma moral) berbeda antara masyarakat dan kebudayaan yang satu dengan masyarakat Demokrasi di Negara Hukum ..... (Catarina Natasha Manurung) 129 dan kebudayaan lainnya, maka norma-norma moralnyapun berbeda-beda. Karena itu disebut relativisme kultural atau relativisme deskriptif (hanya mengungkapkan kenyataan perbedaan norma moral antara kebudayaan yang satu dengan kebudayaan lainnya). Perbedaan antara prinsip moral dasar di satu pihak dan penerapannya di pihak lain, membawa kita kepada perbedaan antara absolutisme moral di satu pihak dan pluralisme moral di lain pihak.

Relativisme etis normatif menyatakan bahwa pandangan moral, mengenai baik atau buruk, hanya didasarkan pada bagaimana orang merasa atau bagaimana suatu kebudayaan menampung keinginan orang-orangnya. Ini menyatakan tiga hal, yaitu: (1) tidak satupun dari kedua penilaian moral ini benar dan tidak satupun salah, karena penilaian moral bukan soal benar atau salah; (2) penilaian 
mengenai benar dan salah ditentukan secara budaya, karena itu penilaian transbudaya tidak punya arti dalam penilaian moral; (3) kita tidak bisa mengatakan tindakan mana yang benar dan mana yang salah, karena kita tak punya cara untuk menentukannya.

Dari teori relativisme etis normatif dapat disampaikan tiga hal, yaitu: (1) moralitas bukan soal perasaan atau pendapat pribadi; (2) ada benarnya penilaian moral ditentukan secara budaya artinya dipengaruhi oleh masing-masing kebudayaan.Tetapi seperti yang disampaikan relativisme moral kultural, di balik penerapan yang berbeda-beda ada prinsip moral universal yang bisa menjadi tolok ukur penilaian moral; (3) apakah benar, kita tidak punya cara untuk menentukan baik atau buruknya suatu tindakan?

\section{Demokrasi Pancasila}

Perkembangan demokrasi di Indonesia telah mengalami masa pasang surut. Masalah pokok yang dialami oleh Indonesia adalah dengan masyarakat yang beraneka-ragam pola budayanya, bagaimana mempertinggi tingkat kehidupan ekonomi dan juga membina kehidupan sosial politik yang demokratis. Bagaimana menyusun suatu sistim politik dengan kepemimpinan yang cukup kuat untuk melaksanakan pembangunan ekonomi serta nation building, dengan partisipasi rakyat juga menghindarkan timbulnya diktatur baik yang bersifat pribadi, partai atau militer.

Pelaksanaan demokrasi di Indonesia haruslah sesuai dengan nilai-nilai demokrasi yang kita anut, antara lain: menyelesaikan perselisihan dengan damai dan secara melembaga, menjamin terselenggaranya perubahan secara damai dalam suatu masyarakat yang sedang berubah, menyelenggarakan pergantian pimpinan secara teratur, membatasi pemakaian kekerasan sampai minimum, mengakui serta menganggap wajar adanya keaneka-ragaman, dan menjamin keadilan. Pelaksanaan demokrasi harus sesuai dengan etika dan nilai-nilai moralitas. Dalam menilai seluruh tindakan kita, kemauan baik harus selalu dinilai paling pertama dan menjadi kondisi dari segalanya. 
Menurut sejarah perkembangan demokrasi di Indonesia dibagi dalam tiga tahap, yaitu: (1) masa Republik Indonesia I, yaitu masa demokrasi (konstitusionil) yang menonjolkan peranan parlemen serta partai-partai disebut demokrasi parlementer (1945-1959); (2) masa Republik Indonesia II, yaitu masa Demokrasi Terpimpin yang dalam banyak aspek telah menyimpang dari demokrasi konstitusionil, yang secara formil merupakan landasannya, dan menunjukkan beberapa aspek demokrasi rakyat (19591965); (3) masa Republik Indonesia III, yaitu masa demokrasi Pancasila yang merupakan demokrasi konstitusionil yang menonjolkan sistim presidensiil (1965).

Beberapa perumusan mengenai Demokrasi Pancasila di dalam beberapa seminar, seperti seminar Angkatan Darat II, musyawarah nasional II Persahi, dan symposium hak asasi manusia.

\section{Seminar Angkatan Darat II,}

Agustus 1966 Saat itu dibahas tentang bidang politik dan konstitusionil, yang terangkum bahwa: (1) Demokrasi Pancasila seperti yang dimaksud di dalam Undang-Undang Dasar 1945, yaitu menegakkan

kembali azas-azas negara hukum di mana kepastian hukum dirasakan oleh segenap warga negara, hakhak azasi manusia dalam aspek kolektif maupun perorangan dijamin, penyalah-gunaan kekuasaan dapat dihindarkan secara institusionil; (2) sosialisme Indonesia, masyarakat yang adil dan makmur; (3) era revolusioner untuk menyelesaikan revolusi yang cukup kuat untuk mendorong Indonesia ke arah kemajuan sosial dan ekonomi

. Sementara itu, dalam bidang ekonomi, terangkum bahwa demokrasi ekonomi sesuai azas-azas yang menjiwai ketentuan-ketentuan mengenai ekonomi dalam Undang-Undang Dasar 1945, kehidupan yang layak bagi semua warga negara mencakup: pengawasan oleh rakyat terhadap penggunaan kekayaan dan keuangan negara; koperasi; pengakuan atas hak milik perorangan dan kepastian hukum dalam penggunaannya; peranan pemerintah yang bersifat pembina, penunjuk jalan serta pelindung;

\section{Musyawarah Nasional II Persahi: The Rule of Law, December 1966}

Dalam musyawarah nasional itu, terangkum bahwa azas negara hukum Pancasila mengandung prinsip: (1) pengakuan dan perlindungan hak azasi yang mengandung persamaan dalam bidang politik, hukum, sosial, ekonomi, kulturil 
dan pendidikan; (2) peradilan yang bebas dan tidak memihak; (3) jaminan kepastian hukum.

\section{Symposium Hak Azasi Manusia, Juni 1967}

Dalam symposium ini dibahas tentang persoalan hak azasi manusia dalam kehidupan kepartaian di tahun-tahun mendatang harus ditinjau dalam mencapai keseimbangan yang wajar meliputi tiga hal, yaitu: (1) adanya pemerintahan yang mempunyai cukup kekuasaan dan kewibawaan; (2) adanya kebebasan yang sebesar-besarnya; (3) perlunya membina rapidly expanding economy.

\section{PENUTUP}

Indonesia adalah negara yang berdasarkan atas hukum (Rechtsstaat) bukan berdasarkan atas kekuasaan (machtsstaat). Demokrasi yang dianut di Indonesia yaitu demokrasi yang berdasarkan Pancasila. Nilai pokok dari demokrasi konstitusionil jelas tersirat dalam Undang-Undang Dasar 1945, yang menyebut secara eksplisit dua prinsip yang menjiwai naskah Undang-Undang Dasar 1945 dan dicantumkan dalam Penjelasan mengenai sistim pemerintahan negara yaitu: Indonesia adalah negara yang berdasarkan atas hukum dan Sistim Konstitusionil. Pelaksanaan demokrasi di Indonesia yang sedang berjalan sekarang ini haruslah sesuai dengan nilai-nilai demokrasi antara lain: menyelesaikan perselisihan dengan damai dan secara melembaga, menjamin terselenggaranya perubahan secara damai dalam suatu masyarakat yang sedang berubah, menyelenggarakan pergantian pimpinan secara teratur, membatasi pemakaian kekerasan sampai minimum, mengakui serta menganggap wajar adanya keanekaragaman, dan menjamin keadilan. Demokrasi di negara hukum juga haruslah sesuai dengan prinsip-prinsip etika dan juga moralitas sehingga selalu berjalan pada rel yang benar. Moralitas yaitu sistem nilai tentang bagaimana kita harus hidup secara baik sebagai manusia. Moralitas adalah tradisi kepercayaan, dalam agama atau kebudayaan, tentang perilaku yang baik dan buruk. Sedangkan etika sebagai sebuah cabang filsafat berbicara mengenai nilai dan norma moral. Ada dua macam etika yaitu etika deskriptif dan etika normatif. Secara umum kita dapat membedakan dua macam norma yaitu norma khusus dan norma umum. Normanorma khusus adalah: aturan yang berlaku dalam bidang kegiatan atau kehidupan 
yang khusus. Norma umum mempunyai sifat keberlakuan yang lebih umum dan universal. Norma umum ini ada tiga macam meliputi: norma sopan-santun (etiket), norma hukum dan norma moral.Dalam menilai seluruh tindakan kita, kemauan baik harus selalu dinilai. 


\section{DAFTAR PUSTAKA}

Friedrich, C. J. (1963). Man and his government, New York: McGraw-Hill. Mayo, H. B. (1960). An Introduction to Democratic Theory, Oxford University Press. Suseno, F. M. (1987). Etika Dasar, Masalah-masalah pokok filsafat moral. Yogyakarta: Kanisius. 
